\title{
The Life of " $8 \mathrm{~K}$ ", a Vagrant Microscope Objective
}

Christoph Lüthy

\section{Summary}

The aim of this article is to suggest that some scientific instruments may be considered worthy of their own biographies and that such a genre may have its own merits and charms. The instrument chosen to exemplify this point is a Hartnack microscope objective lens of about 1860 which served, in turn, the histologist and anatomist Albert von Kölliker, the comparative anatomist Robert Wiedersheim, the surgeon Frederic Kammerer, and the embryologist Edmund Beecher Wilson, and which travelled from Paris to New York by way of Würzburg, Genoa, and Freiburg. Despite a fairly discouraging archival situation, the search for the circumstances surrounding the various employers of " $8 \mathrm{~K}$ " allows us to view the role of microscopes in nineteenth-century biology from a new angle. In additon, the fate of " $8 \mathrm{~K}$ " itself endows this objective with a symbolical significance which transcends its specific functions.

\section{Introduction}

In 1856, Johannes Müller, the famous physiologist and pioneer of microscopy, reported on a recent nautical catastrophy in the North Sea:

"About 50 people have died. It happened in tranquil waters around midnight under a very clear sky. Three beautiful instruments now lie at the bottom of the sea, two by Schieck and one by Kellner ${ }^{1} . "$

It appears that the loss of the three microscopes affected Müller at least as much as the human casualties, for while the latter remained an anonymous mass, he mentioned the "three beautiful instruments" by name.

1 Quoted from A. v. Kölliker, Aus meinem Leben (Leipzig, 1899) 62-63, fn.

Christoph Lüthy (Ph. D.), Istituto Svizzero, Villa Maraini, Via Ludovisi 48, I-00187 Roma 


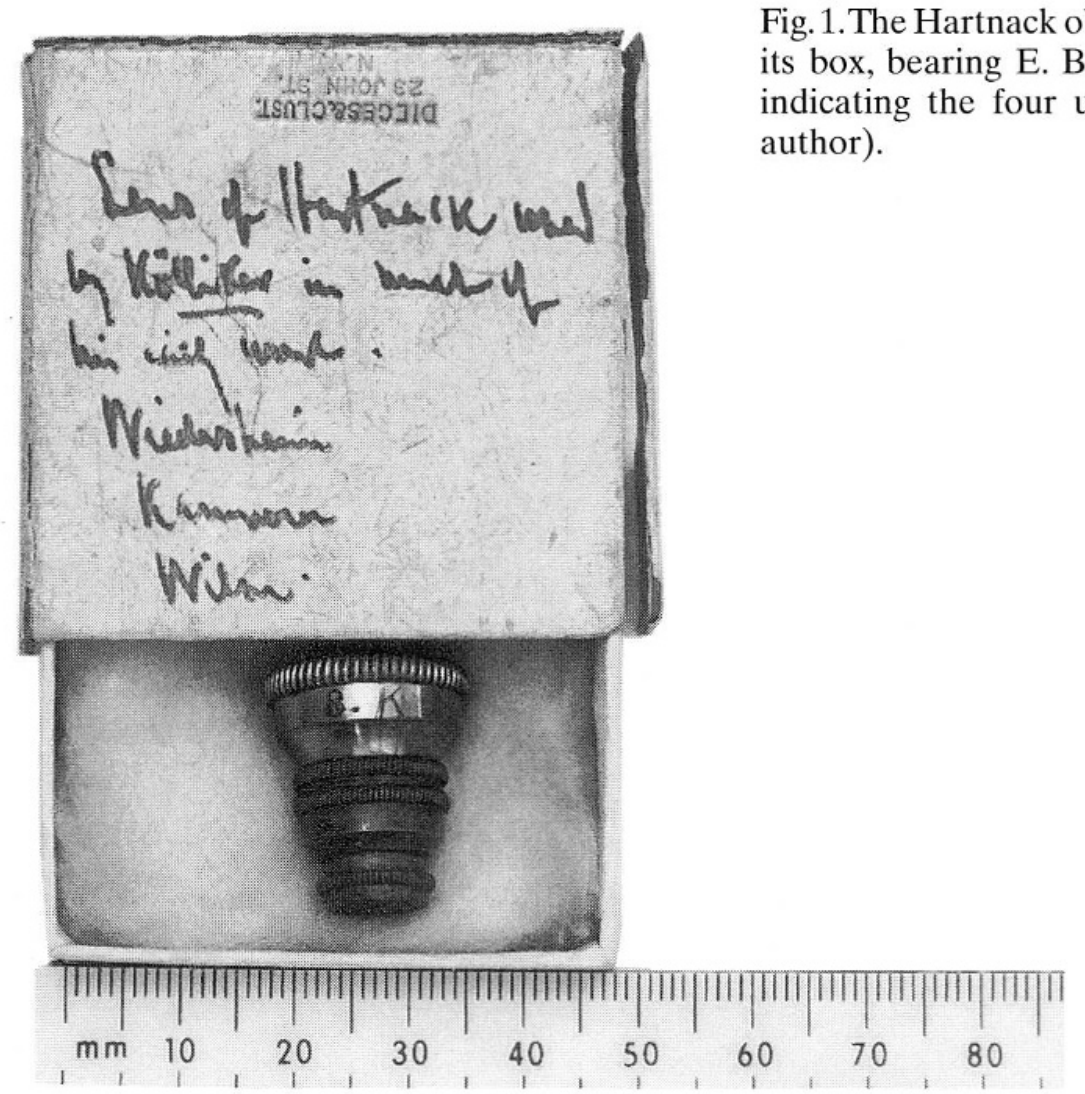

That books have their own lives - habent sua fata libelli - is a commonplace. The same claim, however, should be made on behalf of scientific instruments. Ever since the seventeenth century, much of the rhetoric of scientific objectivity has hinged on the claim that instruments can produce neutral facts, mitigate between us and nature, and amplify her signs. Although it would be misleading to attribute to scientific instruments agency in any traditional sense of the word, the history of scientific practice is nonetheless replete with scientists who thought of their particular instruments as their agents, servants, or collaborators.

If instruments can have a life, then some might deserve their own biographies. The present article attempts to demonstrate that such a genre would not be without its merits. " $8 \mathrm{~K}$ ", the microscope objective to which these pages are devoted, appears well suited to illustrate this point. In its time, it was an excellent instrument, and its employment fell in a period in which the revolution of the biological sciences was to a large extent due to the microscope; it was used by a cascade of celebrated scientists; and finally, s̉everal aspects about its travels and its fate made it assume a symbolical significance beyond its scientific employment. 
The objective lens in question resides in a small and well-thumbed cardboard box in the Collection of Historical Scientific Instruments at Harvard University (inv. no. 1989-32). The box bears the following inscription (Fig. 1):

Lens of Hartnack used

by Kölliker in much of

his early work.

Wiedersheim

Kammerer

Wilson.

For its two distinguishing marks, an engraved " 8 " and a scratched-on "K", we shall call it by the name of " $8 \mathrm{~K}$ " 2 . It is an achromatic non-immersion system by Hartnack (d'ancienne construction) made up of a strong crown-glass plano-convex front lens and two plano-convex crown/flint-glass doublets. Upon measurement, its effective focal length was found to be $2.92 \mathrm{~mm}$, which corresponds to the value given in the original Hartnack catalogues. Its numerical aperture can no longer be measured accurately but must originally have been above 0.75 , an exceptionally high value for the early $1860 \mathrm{~s}$, when it was constructed ${ }^{3}$. Hartnack's no. 8 d'ancienne construction magnified between 250 and 800 times, depending on the oculars employed in combination with it, and its price remained stable at 40 francs until the $1880 \mathrm{~s}$.

The inscription on the box is in the hand of the famous American embryologist and cytologist Edmund Beecher Wilson (1856-1939) ${ }^{4}$. Professor

2 It is unclear whether "K" stands for "Kölliker" or for "Kammerer".

3 Système 8 is a rare objective. Hartnack's 1878 catalogue shows that of the 11 types of microscopes on sale, only one (no. VIII, "neues kleines Stativ") included objective no. 8 in its standard set. Most others included systems 4,7 and 9 and, occasionally, 2 and 5. These are in fact the combinations found in all of the ten Hartnack microscopes at Harvard. The Hartnack in Florence (inv. no. 3268), which is accompanied by systèmes 4,7 , and 8 , seems to be an example of type no. VIII, cf. Turner, op. cit. (n. 13) 80 . Because of its rarity, it has proven to be very difficult to settle beyond doubt whether " $8 \mathrm{~K}$ " is d'ancienne construction (initiated around 1860) or de nouvelle construction (initiated in 1864). Unfortunately, optical tests have not been conclusive. S. D. Fantone, who has courteously tested " $8 \mathrm{~K}$ ", has found a numerical aperture of 0.49 . But even under the assumption that " $8 \mathrm{~K}$ " is d'ancienne construction, the original NA must have been considerably higher, cf. the Prix-Courants des microscopes achromatiques de E. Hartnack et Cie (Paris, 1860, etc.) and the performance tests in H. Frey, Das Mikroskop und die mikroskopische Technik. Ein Handbuch für Ärzte und Studirende (Leipzig, 1863, 1865, 1868, 1873, 1877, 1881). According to J. C. Deiman, the Hartnack non-immersion objective lens no. 8 (presumably de nouvelle construction) at the University Museum, Utrecht (inv. no. UM28) has a comparable focal length of $2.78 \mathrm{~mm}$ but a numerical aperture of 0.9 which (in combination with a $\times 5$ Huygens eyepiece) resolves the dots of Pleurosigma angulatum. The low measured value of " $8 \mathrm{~K}$ " is due partly to residual dirt traces and partly to a small displacement of the middle doublet.

4 J.A. Moore, letter to the author, 19 December 1991. A comparison with samples of Wilson's handwriting preserved at Harvard's Museum of Comparative Zoology corroborates Moore's identification. 
John A. Moore, who met Wilson in his undergraduate days and later became the owner of this piece, assumes that Wilson had himself used " $8 \mathrm{~K}$ " before putting it into its box ${ }^{5}$. Moore himself received the lens around 1950 from the zoologist Franz Schrader (1891-1962), a former student of Wilson's, who inherited the lens presumably when Wilson "was cleaning out his belongings" upon his retirement ${ }^{6}$.

So much information, but not more, can be collected by oral history. What happened to " $8 \mathrm{~K}$ " before its own retirement has to be reconstructed from written sources. To this end, we shall proceed chronologically, following the names on the box.

\section{"Lens of Hartnack ..."}

The modern age of microscopy was ushered in with the development of achromatic microscope lenses in the 1820s and 1830s, and it is well known that the rapid development of the biological sub-disciplines of anatomy, physiology, cytology, histology, and embryology was intimately linked to the development of powerful optical tools ${ }^{7}$. As early as 1845, Rudolf Wagner's Lehrbuch der speziellen Physiologie stated that "without the microscope [...], the study of physiology can no longer be carried out" and predicted that "within a matter of a few years, every student will have to buy his own microscope right at the beginning of his studies".

The sudden and steadily growing demand for high-quality microscopes led to a fast race for technical superiority in the field. Not only companies, but entire nations took part in a competition in which success and failure were measured against the background of constantly rising levels of magnification and image resolution and of the ever more densely drawn lines on Nobert's test-plates. If, in Gerald Turner's phrase, the best microscopes defined the "technical frontier in science", the frontier was moving swiftly. So rapid were

5 J.A. Moore, letter to W. R. Andrewes, Curator, Collection of Historical Scientific Instruments, Harvard, 31 May 1989, on the occasion of his donation of the lens.

6 J. A. Moore, letter to the author, 28 November 1991.

7 Cf. J. W. Wilson, "The Advancement of Biology by Modern Microscopy", American Microscopical Society - Transactions 72 (1953) 91-94. G.L'E. Turner: "The Microscope as a Technical Frontier in Science", Proceedings of the Royal Microscopical Society 2 (1967) 175-199. J. H. Cassedy, "The Microscope in American Medical Science, 1840-1860", Isis 67 (1976) 76-97.

8 R. Wagner, Lehrbuch der speziellen Physiologie (3rd ed., Leipzig, 1845) x. 
hard to stay ahead of the race, but began to lose it around $1880^{15}$. " $8 \mathrm{~K}$ " is a système 8, which makes it Hartnack's strongest non-immersion lens. In 1865 , Frey managed to resolve with it the fields of the Pleurosigma angulatum, a feat he wrote that only Amici, Nachet, and a couple of "English artists" managed to parallel, though by means of much more expensive tools ${ }^{16}$. With a range of magnification between $250 \times$ and $800 \times$, système 8 was an ideal instrument for histologists. As late as 1881, Frey claimed that Hartnack's microscopes were the Continent's best, and that his standard set of lenses 4 and 7, when completed with an 8, "sufficed for all regular investigations"17.

Having established the pre-eminent quality of Hartnack's système 8, it may not surprise us to learn that it was a formidable histologist who purchased and first employed our " $8 \mathrm{~K}$ ".

\section{“... used by Kölliker in much of his early work ..."}

His Excellency Rudolf Albert von Kölliker (1817-1905), Knight of the Bavarian Maximiliansorden für Wissenschaft und Kunst, was 85 years old when he decided in 1902 to step down as the director of the microscopical institute of Würzburg's medical school. In 1847, he had arrived as young professor Albert Kölliker to teach physiology and comparative anatomy, also assuming ex officio the responsibility for the world's very first microscopical university institute, set up only a few years earlier by Franz von Rinecker ${ }^{18}$. With the help of Franz Leydig, Rinecker's former assistant, Kölliker quickly developed his famous microscopy course, "the first of its kind in Germany and probably elsewhere" 19 , and one which he supervised with great love for the 55 years

15 In 1879, Abbe manufactured the prototype of a homogeneous cedar oil immersion lens with a NA superior to Hartnack's. One can retrace the gradual victory of Zeiss over Hartnack in the successive editions of L. Dippel, Das Mikroskop und seine Anwendung (Darmstadt, 1867, etc.). van Heurck, op. cit. (n. 13) 7th ed., pp. 144-148, reported in 1891 that Hartnack had just come out with a new series of objective lenses (systems 5-9) which surpassed his recent homogeneous and water immersion lenses of NA 1.27, adding that “M. Hartnack s'est constamment tenu au courant des progrès de la micrographie et sa maison compte toujours parmi les premières de notre époque".

16 Frey, op. cit. (n. 3) 2nd ed., 1865, pp. 36ff.

17 Ibid., 7th ed., 1881, p. 53.

18 Kölliker, op. cit. (n. 1) 32-33, 39. The Würzburg institute was founded before Purkinje's Prague institute of 1851, despite contrary claims made in much of the current literature; cf. Ph. Stöhr, "Gedächtnisrede auf Albert von Koelliker", Verhandlungen der physikalischmedizinischen Gesellschaft zu Wïrzburg 38 (1906) 277-298, here p. 283.

19 Kölliker, op. cit. (n. 1) 181; cf. J. Sobotta, "Albert von Koelliker. Ein Nachruf”, Münchner medizinische Wochenschrift 52 (1905) 2498-2503, here p. 2499. 
he remained in charge of the institute. By the time of his death, Würzburg was second only to Berlin in the field of microscopical education ${ }^{20}$.

Kölliker's life as a scientist is indeed unthinkable without the existence of microscopes, and if he was allowed to die as a Bavarian dignitary, he owed his fame above all to his mastery of this instrument and of the dissecting, mounting, dyeing, and observational skills surrounding its successful employment. His autobiography reflects the long history of a passion that had been aroused at one of the earliest possible moments. Together with his friend Carl Nägeli, Kölliker had left Zürich in 1839 at age 22 to study for three semesters under Johannes Müller and others in Berlin. There he was introduced to the microscope by Jakob Henle, one of Müller's students, who taught at a small table in the corridor in front of his office, where five or six microscopes had been placed. In this improvised space, Henle also explained the new discipline of histology and Schwann's cellular theory, and in Kölliker's mind, the association between the instrument, the scientific discipline, and the theory would remain inseparable for the rest of his life ${ }^{21}$.

Fascinated by the possibilities of the instrument, Nägeli and Kölliker spent the summer of 1840 on the North Frisian islands of Föhr and Heligoland, accompanied by a Chevalier microscope borrowed from a Zürich physician. "We alternated in the use of this microscope, one day at a time. Whenever Nägeli had the microscope, I went hunting", Kölliker reported to his mother ${ }^{22}$.

Two years later, he had become Dr. Kölliker and owned his own microscope, a Schieck, with which he spent the summer of 1842 in the Bay of Naples ${ }^{23}$. There he shared his room with "five to six buckets of animals on the floor, the tables full of glasses with living animals, a microscope, instruments, a chest of drawers full of spirits of wine "24, and before long, this improvised laboratory had yielded enough important discoveries - notably the monocellular structure of certain animal organisms such as the gregarina ${ }^{25}$ for him to expect "a certain reputation, especially in Germany, which is all I desire" 26 .

20 R. Lerner, "Albert von Kölliker", Geschichte der Mikroskopie. Leben und Werk großer Forscher. Vol. II. Medizin, H. Freund \& A. Berg, eds. (Frankfurt, 1964) 201-213; here p. 212.

21 Kölliker, op. cit. (n. 1) 8. On the connection between cell theory and microscopes, cf. W. Coleman, Biology in the Nineteenth Century: Problems of Form, Function, and Transformation (Cambridge, 1971) 22.

22 Letter of 10 Sept. 1840, in: Kölliker, op. cit. (n. 1) 51.

23 Ibid., 9.

24 Letter of 7 May 1842, ibid., 68.

25 Lerner, op. cit. (n. 20) 211.

26 Letter of 5 Sept. 1842, in: Kölliker, op. cit. (n. 1) 79. 


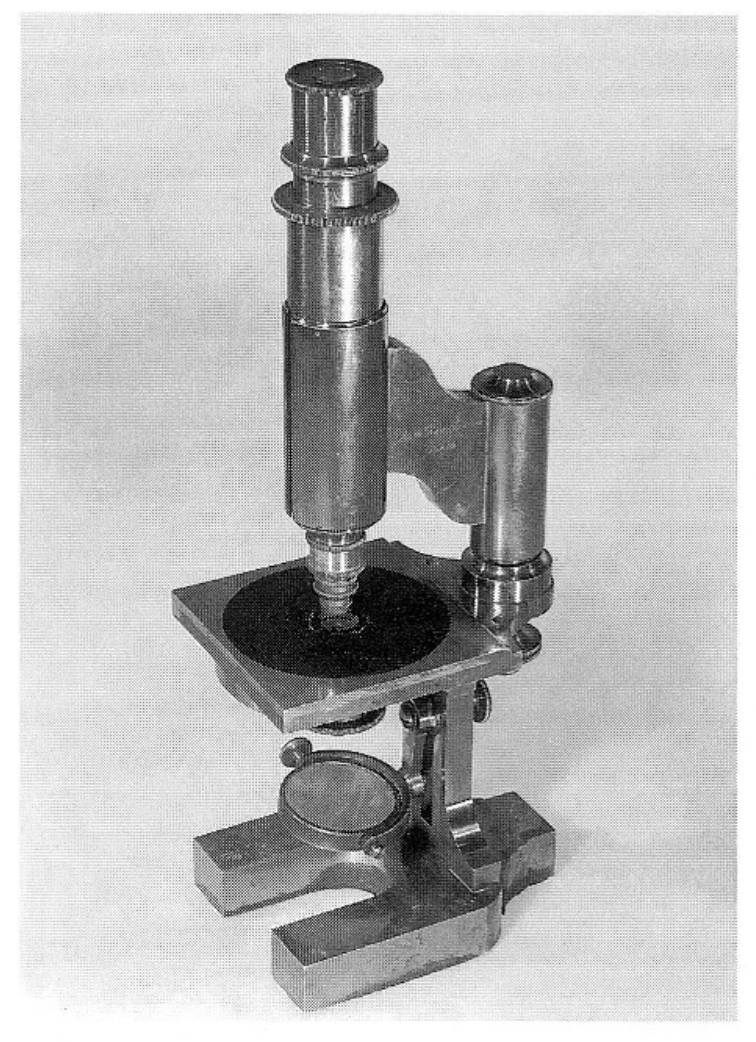

Fig. 2. The old Oberhäuser/Hartnack horseshoe microscope, ca. 1860. Inscriptions: "E. Hartnack"/ "Place Dauphiné, 21, Paris." (inv. no. 1141; courtesy of Collection of Historical Scientific Instruments, Harvard University).

His hopes were not dashed. In 1847, when Würzburg was looking for a physiologist who was "also capable of representing microscopical and comparative anatomy", Kölliker seemed the perfect choice ${ }^{27}$. At a time in which "Valentin's double knife was the only available instrument" for preparing specimens ${ }^{28}$, Kölliker established histology as an independent branch of biology, separating it from its physiological past and linking it firmly to anatomy, a discipline that he also tackled from a microscopical point of view ${ }^{29}$. Investigating with extraordinary scrupulousness every single type of tissue and organ with respect both to comparative anatomy and to evolution, he managed to narrow the number of elementary tissues down from Bichat's 21 to ten in 1852 and to four by $1859^{30}$.

His conviction that competence in the new biological disciplines was dependent on microscopical prowess found support on his many travels. Thus he illustrated the backwardness of the Spanish research institutes he visited in 1849 with the following example:

\section{Ibid., 15.}

28 Stöhr, op. cit. (n. 18) 281.

29 Sobotta, op. cit. (n. 19) 2501. W. Waldeyer, "Albert von Koelliker zum Gedächtnis", Anatomischer Anzeiger 48 (1906) 539-552, here p. 543.

$30 \mathrm{Cf}$. the various editions of Kölliker's famous Specielle Gewebelehre (Leipzig, 1850, etc.). 
"Of the director [of Madrid's Museo di ciencias naturales], Graells, I must tell you a sweet little story. The man had a great French microscope standing in his room. When I asked him what it was that he was investigating, he admitted that he had never had the chance of taking microscopical instruction and did not know how to use the instrument" 31 .

Let us now locate " $8 \mathrm{~K}$ " in this microscope-centered life. We know from Kölliker's recommendations and his own publications that while in the $1850 \mathrm{~s}$, he had favored instruments by Kellner, Plössl, Schieck, and by Hartnack's predecessor, Oberhäuser, he swore by Hartnack's during the 1860s and '70s. In the fifth edition of his Handbuch der Gewebelehre (1867), he wrote that "in the realm of small, affordable, but still eminently usable microscopes for students and physicians, Hartnack [...] offers the best product"32 (Fig. 2). Only in the late 1880s did he begin to use and recommend the powerful new Zeiss and Leitz microscopes ${ }^{33}$.

He chose his instruments scrupulously, knowing that each technical improvement meant that one could "see farther by a substantial degree into the depth of the organic structure "34. The change from Kellner to Hartnack, for example, was accompanied by a marked improvement in visibility and resolution. Forced in 1866 to correct his faulty 1856 illustration of the cross section of a frog muscle, Kölliker explained that "we did at the time not yet possess lenses as good as today's". "With good lenses (systems 8, 9, and 10 by Hartnack)", he added, one could now discern Cohnheim's structures even in the muscles of $\mathrm{a} \mathrm{crab}^{35}$.

Whereas references such as these make it easy to document Kölliker's extreme fondness for Hartnack's instruments in general, and for système 8 in particular, we are far less fortunate in our understanding of his specific employment of " $8 \mathrm{~K}$ ". For together with the rest of Würzburg's university library, Kölliker's estate burnt down during World War II, and the same fate befell the Anatomical Institute, where most of his instruments, the purchase lists, and the rest of his legacy had been preserved. Today's Institute, though located at Köllikerstraße, possesses no original documents ${ }^{36}$. All we know with

31 Letter of 14 Sept. 1849, in: Kölliker, op. cit. (n. 1) 109.

32 A. Kölliker, Handbuch der Gewebelehre des Menschen. Für Aerzte und Studirende (Leipzig, 1852) 6; ibid. (3rd ed., 1859) 6; and ills. 157, 158, 166; ibid. (5th ed., 1867) 5.

33 Ibid. (6th reworked ed., vol. 1,1889) Introduction.

34 Ibid.

35 A. Kölliker, "Ueber die Cohnheim'schen Felder der Muskelquerschnitte", Zeitschrift für wissenschaftliche Zoologie 16 (1866) 374-382, here p. 374-5.

36 G. Sprenger, Bibliotheks-Amtsrätin, letter to author, 2 March 1992. E. Asan, Anatomisches Institut, to author, 6 April 1992. According to P. Brenni (letter to author, 14 September 1992) Hartnack's sales lists are also lost. 
burg, this time as Kölliker's assistant and prosector ${ }^{38}$. In the latter capacity it was his turn to teach the famous microscopy course in $1875^{39}$.

His passion, however, lay not with microscopical anatomy, but with comparative anatomy and zoology, and "hence there was little help I could expect from Kölliker". When Professor Ecker offered him a position as prosector in comparative anatomy at Freiburg in the summer of 1876, Wiedersheim tried to bargain with Kölliker for a comparable position at Würzburg, but without success. A few days later, he left, rather disgruntled, for his new position $^{40}$.

A few months before this separation, Wiedersheim had published an important article on salamanders in a Genoese journal ${ }^{41}$. Of its 141 illustrations, a limited number displayed highly magnified objects, all and sundry studied with the help of Hartnack lenses. One of them in particular (Fig. 3), representing the spermatozoa of a geotriton, is indicated as having been drawn with the help of a Hartnack lens no. 8.

We may be confident in assuming that this lens was our very " $8 \mathrm{~K}$ ". First, Wiedersheim used a fairly complete - and hence expensive - set of strong Hartnack lenses for his observations, which he is unlikely to have have owned. This is particularly true for système 8 , which we have already defined as a very rare piece. We know, furthermore, that the salamander article was written while Wiedersheim was in charge of Kölliker's microscopy course. The author, who signs as "Prosector an der Anatomie zu Würzburg", addresses words of gratefulness to "Herrn Geheimrath von Kölliker" such expressions of gratitude would typically have included the permission to use the institute's tools. Finally, the year 1875-1876 is the last obvious moment in which Kölliker would have given his " $8 \mathrm{~K}$ " to Wiedersheim. A few months later, his former prosector was already in Freiburg, and although he later contributed to two of the Festschriften for Kölliker ${ }^{43}$ and attended one

39 Wiedersheim, op. cit. (n. 37) 69. On the functions of the "Prosektor", cf. H. Schierkorn: "Der Prosektor und seine Stellung in der Hierarchie der anatomischen Institution ...", Anatomischer Anzeiger 159 (1985) 311-346. At Freiburg i.Br., the Dienstvorschrift für Prosektoren of 1865 states: "The prosector is the assistant of the director of the anatomical institute." His task was to a) prepare the specimens; b) act as the curator of the anatomical collection; c) assist the director during dissection exercises in class. Quoted from W. Neuland, Geschichte des Anatomischen Instituts und des Anatomischen Unterrichts an der Universität Freiburg i. Br. (Freiburg, 1941) 169.

40 Wiedersheim, op. cit. (n. 37) 60-73.

41 R. Wiedersheim, "Salamandra perspicillata und Geotriton fuscus, Versuch einer vergleichenden Anatomie der Salamandrinen", Annali del Museo Civico di Genova 7 (1875).

42 Ibid., 19.

43 Festschrift Albert von Kölliker zur Feier seines siebenzigsten Geburtstags gewidmet von seinen Schülern (Leipzig, 1887); Festschrift der Zeitschrift für wissenschaftliche Zoologie ... (Leipzig, 1892). 
of the celebrations held in his teacher's honor ${ }^{44}$, contact between the two men was at best sporadic and lacking in warmth ${ }^{45}$.

Wiedersheim's own life ended far less glamorously than Kölliker's. After having presided over a highly successful and rapidly growing medical school, Wiedersheim witnessed the dramatic undoing of his life's work. In 1917, English bombs destroyed his Anatomical Institute ${ }^{46}$ :

"The anatomical, comparative anatomical, and embryological teaching collections, together with all pedagogical materials, amongst them 200 microscopes and more than 2000 diagrams, all fell prey to the flames" 47 .

His own international reputation and his association with his brother-in-law, August Weismann, with Haeckel, von Siebold and others had allowed him to develop a patriotic pride in what he understood to be German supremacy in the biological sciences, and he was ill equipped to accept this unpleasant turn of events. Shaken and embittered, he gave his last lecture in June, 1918, and retired to his country home on Lake Constance where he awaited, with increasing fervor, the day of retaliation ${ }^{48}$.

Wiedersheim's use of " $8 \mathrm{~K}$ " after 1876 must have been scarce. The comparative anatomical studies he published between the late 1870 s and the early 1900 s hardly ever refer to magnifications exceeding a factor of $100 \times$. In fact, he quickly parted with his Würzburg souvenir, bequeathing it to Frederic Kammerer.

\section{“... Kammerer ..."}

Whereas " $8 \mathrm{~K}$ " managed to leave Freiburg before the flames consumed Wiedersheim's institute, the archival record of Frederic Kammerer, its third owner, did not escape destruction, which explains why his role at Freiburg has been forgotten.

44 Kölliker, op. cit. (n. 1) 196.

45 Ibid., 34, 38, 173. Cf. Kölliker's attack on Wiedersheim in the Morphologisches Jahrbuch 3 (1877) 365, 453. No letters between Kölliker and Wiedersheim seem to have been preserved (G. Keil, Würzburg, letter to author, 5 August 1992; J. Staubesand, Freiburg, letter to author, 24 July 1992; E. Wiedersheim, Lindau, letter to author, 6 August 1992).

46 The number of students enrolled at his institute grew from 100 in 1871 to 3000 in 1911, and growth was particularly strong during his directorship, partly because of the international reputation of Wiedersheim's text-books, especially in the United States. Cf. Grote, op. cit. (n. 38) 213-216; E. Fischer, "Die Anfänge der Anthropologie an der Universität Freiburg i.Br.", in Anthropologischer Anzeiger 3 (1926).

47 Grote, op. cit. (n. 38) 222; cf. E. Fischer, op. cit. (n. 46) 383.

48 On the overall nationalist mood of the faculty at Freiburg's medical school, cf. E. Seidler: Die Medizinische Fakultät der Albert-Ludwigs-Universität Freiburg im Breisgau (Berlin, 1991). 
Frederic Kammerer (1856-1928) was born in New York to a Swiss father and an Austrian mother. At the age of 16 he was sent to the Karlsruhe Polytechnic; from 1876 to 1880 , he studied medicine at Freiburg ${ }^{49}$. According to his obituaries, he worked "for one year, 1878 to 1879", as "assistant in the Anatomical Institute of Professor Robert Wiedersheim "50, a claim that we shall discover to be inaccurate. After receiving his M.D., he transferred to the Surgical University Clinic in Freiburg. Brief stints with Carl Schroeder in Berlin and Ludwig Lichtheim in Berne preceded his return, in 1886, to New York where he took up surgery at the German Hospital and later at the Lenox Hill Hospital. He held several consulting posts and was professor of surgery at the College of Physicians and Surgeons at Columbia University from 1909 to $1921^{51}$. In 1921, he retired to Berne and died in Merano seven years later ${ }^{52}$. Even during his New York years, Kammerer remained torn between his two continents. From November 1915 to May 1916, he headed a hospital unit of the American Physicians' Expedition Committee to help wounded Germans in Western Prussia, but upon the United States' entry into the war was commissioned by the opposite side and served as a Major in the U.S. Army's Medical Corps.

This torn man has left no traces in the archives of New York or Berne and, as reported, has even dropped out of the institutional memory of Freiburg University $^{53}$. By the time Werner Neuland tried to reconstruct the complete list of all assistants and prosectors in 1941, the existence of Kammerer had shrunk to the size of a question mark: as assistants, he mentioned one Dr. Calberla (for 1877-1878) and one Dr. Kühn for "1878(?) to 1879". The truth is, however, that Dr. Calberla fell ill and had to be replaced, and that it was cand. med. Kammerer who filled in for one semester ${ }^{54}$.

49 The only biographical information of some substance on Frederic Kammerer is contained in two almost identical obituaries by De W. Stetten, Transactions of the Academy of Surgeons 46 (1928) 488-491, and in Annals of Surgery 89 (1929) 315-318.

50 Ibid., 488.

51 "Kammerer", Who was Who in America, vol. 1, 1897-1942 (Chicago, 1942).

52 "Kammerer, Frederick", The National Cyclopaedia of American Biography 23 (New York, 1923).

53 The only archival material on Kammerer to be found in Berne (Stadt- und Universitätsbibliothek, Med. var. 1273) is a signed offprint of F. Kammerer and G. de Giacomi "Zur quantitativen Bestimmung der in der Luft enthaltenen Keime”, Archiv für experimentelle Pathologie und Pharmakologie 21 (1886) 318-339, written during Kammerer's brief stage at Lichtheim's clinic.

54 Neuland knew that 1) Kühn was prosector from 1880 to $1882 ; 2$ ) Calberla fell sick in the summer semester of 1878 and had to be excused; and 3) Kühn was assistant in the summer of 1879, cf. op. cit. (n. 39) 174, 183. It follows that Kammerer (to whose existence Neuland was oblivious) served as assistant for the semester in which Calberla was on sick leave. 
Contrary to what Kammerer's obituaries assume, Wiedersheim was not yet in charge of the Institute, but was still Dr. Ecker's prosector. Yet, Kammerer was Wiedersheim's subordinate both in academic rank and function ${ }^{55}$. Since Ecker was at the time completing his "embryological collection for the study of the developmental history of man and animals" $" 56$, it is likely that Wiedersheim and Kammerer were assigned tasks in the microscope collection.

There is neither evidence that Wiedersheim and Kammerer had any contact beyond the winter semester of 1878-1879 nor that Wiedersheim ever regarded Kammerer as his student. We must therefore assume that it was at the end of those winter months that " $8 \mathrm{~K}$ " changed hands. Beyond gratitude to Kammerer, who had filled the vacant position at such short notice, Wiedersheim may have had further reasons to part with this scientific souvenir. First, he had left Kölliker with a grudge, which diminished the emotional value of " $8 \mathrm{~K}$ ", and second, we have already mentioned that his own research required none or only low powers of magnification.

The air attack of November 1944, which destroyed whatever institutional documents had survived World War I, further reduced Kammerer's chances of rehabilitation ${ }^{57}$. "8K" now emerges as the only material witness, as it were, of Kammerer's presence at Freiburg and of the university's gratitude towards her doctorandus and assistant of 1878-1879.

\section{“... Wilson"}

The details of Edmund Beecher Wilson's life are almost as difficult to trace as those of the lives of the earlier owners of " $8 \mathrm{~K}$ ", although it was not a war that destroyed his records, but the disinterest of his colleagues and successors. "The huge number of illustrations for the Cell [...], piles of manuscripts, notebooks, photographs, and correspondence were discarded" upon his death $^{58}$.

As in the case of Widersheim and Kammerer, " $8 \mathrm{~K}$ " is presently our only indication that Kammerer and Wilson ever met ${ }^{59}$, and we must once more cull all our knowledge from the printed sources. Wilson was born in 1856, like Kammerer, and while the latter was in Europe, Wilson graduated from Yale in 1878 and received his Ph.D. from Johns Hopkins in 1881. His dissertation,

55 On the duties of the prosector at Freiburg, cf. fn. 39.

56 Neuland, op. cit. (n. 39) 231 and 244.

57 E. Seidler, Freiburg, letter to author, 15 July 1992.

58 John A. Moore, "Edmund Beecher Wilson, Class of '81", American Zoology 27 (1987) 794.

59 J.A. Moore, letter to author, 11 February 1992; W. B. Provine, letter to author, 8 January 1992; J. Maienschein, letter to author, 27 January 1993. 
which was devoted to the development of the alcyonarian Renilla reniformis, the sea pansy, was deeply influenced by Kölliker's work of 1872-1873. The same is true of his 1883 Renilla paper for the Transactions of the Royal Society ${ }^{60}$.

Between 1882 and 1883, Wilson visited many of Europe's leading research institutes, but the chronology and itinerary of those travels is not well established ${ }^{61}$. Currently, we only know that he visited Britain, Leipzig and the Naples marine laboratory, but we should like to postulate that he must also have passed through Freiburg, where Kammerer was then employed. For if we accept that Wilson did in fact use " $8 \mathrm{~K}$ ", as he seems to have told Schrader, as Schrader told Moore, as Moore tells us ${ }^{62}$, and as the inscription on the box itself may be taken to suggest, any later date for this change of hands is unlikely. Upon his return to the United States, Wilson taught at a number of places, and it was not until 1892 that he moved to New York, where Kammerer had meanwhile set up his practice. But by that date, " $8 \mathrm{~K}$ " would have been insufficient for the kind of cytological studies Wilson was engaged in. In fact, it appears from the scarce references to optical instruments in his publications that he began to rely on Zeiss in the mid- $1880 \mathrm{~s}^{63}$.

The inscription on the box makes it clear that Wilson was fascinated above all by the fact that " $8 \mathrm{~K}$ " had been used by Kölliker. Indeed, he mentioned Kölliker's name with great frequency and respect throughout his life. In the last edition of his Cell in Development, Wilson cited Kölliker (together with Remak and Nägeli) as providing "those pioneer microscopical researches which ultimately demonstrated that cell-division constitutes the central phenomenon in organic reproduction". He also supported Kölliker in his claim to have antedated Virchow in recognizing the principle of omnis cellula ex cellula in his study on cephalopods. As for cytology, Wilson maintained that "the pioneer studies of Kölliker, Remak, and Hofmeister" had defined its relationship to genetics ${ }^{64}$.

60 A. Kölliker, "Anatomisch-systematische Beschreibung der Alcyonarien, 1. Abtheilung. Die Pennatuliden", Abhandlungen der Senckenbergischen Naturforschenden Gesellschaft 7 (1872) and 8 (1873) 85-275. This work, in turn, included the research of A. E. Verrill, one of Wilson's teachers at Yale. E.B. Wilson, "The Development of Renilla", Philosophical Transactions of the Royal Society, Part III, (1883) 723-815.

61 Moore, op. cit. (n. 58) 787.

62 J.A. Moore, letter to W.R. Andrewes, 31 May 1991.

63 Cf.E. B.Wilson, "Synopsis of the Pycnogonida of New England", Transactions of the Connecticut Academy 5 (1878) 1-26; "The mesenterial Filaments of the Alcyonaria", Mittheilungen aus der Zoologischen Station zu Neapel 5 (1884) esp. p. 26. S. Sedgwick \& E. B. Wilson, General Biology (New York, 1886) Appendix, make reference exclusively to Zeiss objectives $\mathrm{A}$ and D.

64 E. B. Wilson, The Cell in Development and Heredity (3rd ed., New York, 1925) 1, 9, and 15. 


\section{Conclusion}

The history of nineteenth-century biology is to an impressive degree the history of microscopy. Under the impact of the structures made visible by the new instruments, "the old conceptions collapsed like medieval castles under new war machines", as Du Bois-Reymond said in $1860^{65}$.

The obituaries of both Kölliker and Wilson, first and last users of " $8 \mathrm{~K}$ ", duly emphasized the role of excellent optical instruments in the development of the biological disciplines. Stöhr wrote, for example, that "[i]n order to be able to pay due homage to Kölliker's achievements, we have to know that most of the microscopes of that time were exceptionally deficient instruments" ${ }^{\prime 6}$. H. J. Muller explained, in turn, that when Wilson grew up,

"mitosis and the chromosomes had not yet been discovered, nor even that fertilization involves a union of two nuclei, one from each parent. For oil-immersion lenses and Abbé condensors, anilin dyes and section cutting had only just been invented" 67 .

Kölliker and even Wilson were educated at a time in which "the curtain which hides the very small from our gaze" could be lifted "a little further" with every improvement in microscope manufacture ${ }^{68}$. But Kölliker's and Wilson's obituaries needed to draw attention to the deficiencies of nineteenth-century instruments precisely because the pioneering age of microscopy had passed when they were written. Wilson, in contrast to Kölliker, hardly ever felt the need to mention the optical instruments he used. By the time he published his later work, magnification was the least controversial part about a microscopical discovery. What required explanation were rather the methods employed in making cytological structures visible. Wilson's work within the framework of what Wilhelm Roux called 'experimental morphology' or 'experimental embryology' involved an arsenal of new methods, and there is hardly a paper in which he did not dedicate at least a footnote to his techniques, specifying whether he had used Perenyi's or Lang's fluid, and whether borax, picro, or alum carmines had been used for the staining of tissues ${ }^{69}$.

As Deiman rightly emphasizes, before the age of standardization, i.e. "ca. 1880, when the Germans started producing great numbers of objectives

65 E. Du Bois-Reymond, "Gedächtnisrede auf Johannes Müller", Abhandlungen der Königlichen Akademie der Wissenschaften, 1859 (Berlin, 1860) 25-191.

66 Stöhr, op. cit. (n. 18) 281.

67 H.J. Muller, "Edmund B.Wilson - An Appreciation", The American Naturalist 77 (1943) 5-37; $142-172$, here p. 6.

68 E. M. Nelson, quoted from Bradbury, op. cit. (n. 13) 268.

69 Cf. Garland Allen, Life Science in The Twentieth Century (New York, London, 1975) 25. 
within close tolerance, the differences between the individual objectives were too large to neglect" 70 , and micro-biological discoveries could be due to the superb quality of an individual lens. This phenomenon was nicely captured by Oliver Wendell Holmes, who wrote in 1877 that "every microscopist goes through a period of combative excitement about his objectives if he has any remarkable ones" $"$.

" $8 \mathrm{~K}$ ", very much the product of a pioneering age in microscope manufacture, was just such a remarkable objective, and it is therefore all the more disappointing that the violent destruction of Kölliker's and Wiedersheim's estates and the partial or total loss of Kammerer's and Wilson's have rendered it impossible to document with any greater precision the "combative excitement" " $8 \mathrm{~K}$ " must initially have provoked.

The paucity of specific details about its adventures is, however, partly compensated by the recognition that it alone survived, in some fortuitous manner, the cataclysms of war which destroyed, in Würzburg and Freiburg, all the body-tubes to which it had formerly been attached.

In 1943, H. J. Muller wrote in his beautiful commemorative article on Wilson:

"The fumes of war spreading out from the heart of the region where the cell theory had its first rise are now grievously choking this growth in an ever-wider circle. But science must grow or retrogress" $" 72$

" $8 \mathrm{~K}$ " is almost unique among Kölliker's and Wiedersheim's instruments in having survived the wars of our century. Its passage to the United States and the refuge it found in Wilson's box assume therefore a symbolical air, reminding us of the loss of German supremacy in biological research and the growing prominence of American science in the middle decades of this century.

Wilson himself felt that "the pioneers of progress, and the real conquerors of the world", were not the soldiers on European battle-grounds, but the scientists who, equipped with their very different instruments, pursued with "incorrigible, almost automatic insistence upon verification" the visible phenomena at increasingly fundamental levels. Theirs was not only a peaceful campaign, he felt, but one that offered great hope: "the splendid achieve-

70 J. C. Deiman, Microscope Optics and J. J. Lister's Influence on the Development of the Achromatic Objective 1750-1850 (Ph. D. thesis, University of London, 1992) 8.

71 O. W. Holmes, "An Address delivered at the annual meeting of the Boston Microscopical Society”, Boston Medical and Surgical Journal 96 (1877) 605.

72 Muller, op. cit. (n. 67) 172. 
ments of cell research in the past twenty years stand as the promise of its possibilities for the future, and we need set no limits to its advance"73.

Against the background of the destructive European wars, Wilson's highspirited belief in the inexorable progress of the life sciences evokes images of a Sartonian world in which, out of the cyclical devastations caused by human brutishness, the ever-ascending line of scientific advance rises with unwavering clarity. Taken in this spirit, the list of scientific battle-fields inscribed on the box of " $8 \mathrm{~K}$ " assumes the air of a monument, a memento.

I wish to acknowledge the assistance of Prof. John A. Moore, the former owner and donor of " $8 \mathrm{~K}$ "; of Mr. William R. Andrewes, Curator of the Collection of Historical Scientific Instruments at Harvard University; of Dr. Stephen D. Fantone (Optikos Corporation, Cambridge, Mass.), who tested " 8 K"; of Dr. James G. Baker (Polaroid); and of Dr. J. C. Deiman of the University Museum, Utrecht, who shared his test results of comparable microscope lenses. I also wish to thank Profs. Garland E. Allen, Urs Boschung, Paolo Brenni, Reinhard Hildebrand, Gerald Holton, Myles Jackson, Gundolf Keil, Jane Maienschein, William B. Provine, Eduard Seidler, and Jochen Staubesand as well as Drs. Esther Asan, Lazare Benaroyo, and Eberhard Wiedersheim for their letters and comments. Thanks are also due to the staff of the university libraries and medical schools at Basel, Berne, Freiburg i.Br., New York, and Würzburg.

73 Quoted ibid., 163, 37. 